\title{
Deserting the Wife between Disciplining and Abuse: An Islamic Jurisprudential Study
}

\author{
Orwah Ikrimah Sabri ${ }^{(1)}$
}

\begin{abstract}
This study deals with the topic of wife desertion, or the Islamic legal recourse of temporarily abandoning one's wife as disciplinary action for an act of disobedience committed by the wife. The fuqaha (Muslim jurists) elucidated the methods of desertion such as refusing to sleep in the same bed as one's wife, eschewing of sexual relations, refusing to communicate verbally or otherwise, while also pointing out the lawful duration. Moreover, the adoption of desertion as a means for harming the wife was addressed by the fuqaha as well, and the position of the fuqaha vis a vis the right of the wife to demand separation as a result of this reason through the courts of law, and the period that grants the wife this right, and also the type of separation resulting from the separation ordained by the judge in terms of considering it as a separation/dissolution (faskh) or divorce.

Keywords: Deserting, Disciplining, Abuse, Marriage, Divorce

$$
\text { هجر الزوجة بين التأديب والإيذاء: دراسـة فقهية }
$$$$
\text { ملخص البحث }
$$

يتناول هذا البحث موضيوع هجر الزوجة باعتباره وسيلة من وسـائل تأديب الزوجة عند نشوزها ومخالفة زوجها، وذلك ببيان آراء الفقهاء المتعددة في كيفية الهجر من هجر الفراش أو ترك الجماع أو ترك الكلام وغيرها، وكذلك بيان مدته المشروعاة. كما تم التطرق لحالة اتخاذ الهجر وسيلة من وسـائل إيذاء الزوجة والإضرار بها، وموقف الفقهاء من حق الزوجة في المطالبة بالتفريق لهذا السبب قضائياً، ومقدار المدة التي تعطي الزوجة هذا الحق، وكذلك نوع الفرقة الناتجة عن تفريق القاضي من حيث اعتبارها فسخاً أو طلاقاً. كلمات مفتاحية: الهجر، التأديب، الإيذاء، الزواج، الطناق حيبات
\end{abstract}

(1) Assoc. Prof. of Islamic Jurisprudence, Faculty of Qur’ān and Islamic Studies, Al-Quds University, Palestine. orwasabri@gmail.com

\begin{tabular}{ll}
\multicolumn{2}{c}{ Contents } \\
Introduction & 69 \\
Disciplining the Wife by Desertion & 70 \\
Definition of Hajr and its Islamic Legal Ruling & 70 \\
Method of Desertion & 71 \\
Duration of Hajr & 72 \\
Harming the Wife by Desertion and its Impact & 73 \\
The Right of the Wife to Sexual Intercourse and & 73 \\
Matrimonial Cohabitation & \\
Separation of the Spouses Due to Hajr & 74 \\
Duration of the Hajr Justifying Demand for & 75 \\
Separation and the Type of Separation & 76 \\
Conclusion & 77 \\
Reference &
\end{tabular}

\section{Introduction}

All praise is to Allah, Lord of the worlds, and prayers and peace be upon the Prophet Muhammad, and all his family and companions.

Among the positive features distinguishing the Sharī'ah is that it comprehensively addresses the various interests of people, and it does not confine itself to tackling public issues that concern society but goes beyond that to treat in the finest detail issues related to the private life of the individual Muslim.

This is manifested in rules and principles organizing and governing familial and matrimonial relations, which aim determinedly to affect relations of love and amity between the husband and wife. They tackle the cases in which there could be marital differences through elaborating some Islamic legal rules and norms, including the lawfulness of deserting the wife as a way to discipline her.

This last matter is addressed in the present study aiming to elucidate the reality and nature of this method, and when al-Hajr (desertion) is used to harm one's wife thereby being an unlawful act, and how there could be a role for the judicial body to ward off harm done to the wife resulting from deserting her.

I found a number of previous studies on this topic, and the topic of Hajr was treated in research efforts in an independent manner, in addition to the fact that this topic is manifestly present in the works of Muslim jurisprudence (fiqh). 
Among those works is the study of Ismā' Shindī. entitled "Hukm Hajr al-Zawjah Fī al-Fiqh alIslamī" published in the Journal of Al-Quds Open University in 2015.

This paper deal with the provision of abandonment of the wife in details.

Moreover, the study jointly authored by AlRifā' $\mathfrak{i}$, Rudayna, and Tawālbah, Muhammad entitled “Ahkām al-Hajr F̄̄ al-Fiqh al-Islam $\vec{\imath}$ ' published in Majallah Dirāsāt Ulum al-Sharī‘ah wa al-Qānūn, University of Jordan in 2009.

The research dealt with the rules of abandonment in Islamic jurisprudence in general, which tells to abandon the wife and other perpetrators of $\sin$.

This study is distinguished from the previous studies in that is talks about the provisions of abandonment of the wife as a method of discipline.

And then it shows the provisions resulting from abuse and the legal implications in addition to the validity of judiciary to intervene to end the victimization. It also addresses the extent to which the couple can be separated because of desertion in the case of an abusive husband.

In writing this study I adopt the descriptive methodology, where I present the opinions and proofs of the jurists and thence discuss them and identifiy the more plausible positions, and I also show the locations of the ayāhs (verses) in the Qur'ān, and I authenticated the Prophetic hadīth s from their sources, and I also documented the opinions of the fuqaha relying on the authoritative Fiqh works.

I supplicate Allah that He has given me success in authoring this study, and for it to be reckoned a good deed on the Day of Judgment, for He is Hearing and answers our prayers.

\section{Disciplining the Wife by Desertion}

It includes three subsections:

\section{Definition of Hajr and its Islamic Legal Ruling:}

Al-Hajr linguistically denotes distance and desertion, and it is the antithesis of connectivity. (Ibn Manzuur, 5:250-253; al-Fayrūzabādī, 1:637).

Hajr as a technical term it denotes for a human to separate from another either physically or by tongue or by heart (al-Aṣfahānī, 536; Al-Manāwī, 1990, 1:738).
Disciplining the wife by desertion (Hajr) occurs in the sense of distance, whereby the meaning intended in the Holy Qur'ān is to distance them in the beds (Ibn al-'Arabī, 1:534).

The meaning of Hajr will be elucidated in detail upon discussing the method of Hajr in the next subjection.

As to the rule on Hajr, it is essentially prohibited, because it is impermissible for a Muslim to distance himself from his Muslim brother for more than three days, given the presence of several Prophetic hadiths which forbid a Muslim to abandon his Muslim brother including:

1. The hadìth of Anas Ibn Malek: that prophet Muhammad (S.A.W) said: "Do not hate one another, nor be envious of one another; and do not desert one another, but Allah's worshipers! Be Brothers! And it is unlawful for a Muslim to desert his brother Muslim (and not to talk to him) for more than three nights" (alBukhārī, 1987, 5: 2256; Muslim, 4:1983).

2. The hadīth of Abu Ayyūb al-Anșārī God be pleased with him: that prophet Muhammad (S.A.W) said: "It is not permissible for a Muslim to shun his brother for more than three nights. When they meet, this one turns away (from that one) and that one turns away (from this one) and the best of them is the one who greets his brother first" (al-Bukhārī, 1987, 5:2256; Muslim, 4:1984).

However, Hajr was permitted (is licit) in particular situations, including deserting the wife in case of her rebellion and disobedience of her husband.

Thus the Hanafīs (al-Jassās, 1985, 3:150; alKāssānī, 1982, 2:334; Ibn Nujaym, 3:236), Mālikīs (alDard̄̄ir, 2:343; Aleesh, 1989, 3:545; al-Zarqān̄̄, 2002, 4:105), Shāfì `̄s (al-Shirāzī, 2:487; al-Ramlī, 6:390; alDumayrī, 2004, 7:417), and Hanbalīs (Ibn Muflih, 1980, 7:214, al-Bahūtī, 1982, 5:209), jurists have concurred that a man may desert his wife in case she rebels in order to discipline her, and that desertion is not lawful except after a husband advises and preaches to the wife, and in case she does not positively respond to the advice and insists on her rebelliousness he shall desert her. It should be pointed out in this context that the fuqaha (jurists) disagree on the method of Hajr, which is a matter which I shall clarify in detail in the next topic.

The permissibility of desertion is attested to by several sacred proofs or evidences, including: 
1. As to those women on whose part you see ill conduct, admonish them (first), (next), refuse to share their beds, (and last) beat them (lightly, if it is useful), but if they return to obedience, seek not against them means (of annoyance). Surely, Allah is Ever Most High, Most Great. [An-Nisa: 34]

2. The hadīth of Umm Salamah that the Prophet (S.A.W) swore not to enter the chambers of his wives for one month, and when twenty-nine days passed, he frequented them, whereupon it was said to him, O Messenger of Allah you swore to shun them for one month and he said: "The month is of 29 days" (alBukhārī, 1987, 5:1996; Muslim, 2:764).

3. The hadīth of Amru Bin Al-Ahwass: that Prophet Muhammad (S.A.W) said: "Treat women kindly, they are like captives in your hands; you do not owe anything else from them. In case they are guilty of open indecency, then do not share their beds and beat them lightly but if they return to obedience, do not have recourse to anything else against them" (Al-Tirmidhi 3:467; Al-Nassā’̄̄, 2001, 8:264; Ibn Mājah, 1:594; AlAlbānī, 1985, 7:96-97).

4. The hadīth of Hakim Ibn Mu'āwiyah: that Prophet Muhammad (S.A.W) said: "That he should feed her as he feeds himself and clothe her as he clothes himself; he should not strike her on the face nor disfigure her, and he should not abandon her except in the house -as a form of discipline" (Ibn Mājah, 1:593; Al-Hākem, 1991, 2:204; Al-Bayhaqi, 1994, 7:295; AlAlbānī, 1985, 7: 98).

\section{Method of Hajr (Desertion):}

The fuqaha have differed on how a man would desert his wife through several opinions of which I will cite the most important:

1. The Hanafīs are of the view (Al-Kāssānī, 1982, 2:334; Ibn Nujaym, 3 :236) that desertion is by eschewing oral communication with the wife, and but not eschew sexual intercourse or the matrimonial bed. This opinion was also stated by Ibn Abbas, Ikrimah, AlDahhak and Al-Sadiy (Al-Jașṣāṣ, 1985, 3:150).

The exponents of this view based their view on the premise that sexual intercourse is a joint right of the spouses and its eschewal entails harm to the man, and thus he must not discipline the wife by harming himself and invalidating his right. (Al-Kāssānī, 1982, 2:334).

2. In one saying of the Hanafīs (Al-Kāssānī, 1982, 2:334; Ibn Nujaym, 3 :236), Mālikīs (Al-Hāttāb, 1978, 4:15; Al-Kharashī, 4:7; Al-Zarqān̄̄, 2002,
4:105), Shāfi '̄̄s (Al-Nawawī, 1985, 7:367; Al-Dimyātī, 3:376; Al-Mahallī, 1995, 3:307) and Hanbalīs (Ibn Qudāmah, 1985, 7:242; Ibn Mufleh, 1982, 7:214; AlRuheibānī,5:287) the position that Hajr is to desert the wedlock bed and not to engage in intercourse with the wife.

It is the position of the Hanafis based on this saying that if he has another wife he shall have intercourse with the other from her share, because her share is honored when the rules of God are observed and not in case of disobedience and disputes (AlKāssānī, 1982, 2:334).

3. In one saying of the Hanafîs (Ibn Nujaym, 3:236) and another of the Shāfi 'is (Al-Shirbinī, 3: 259) it is held that desertion is to eschew sexual intercourse with the wife and not to desert the wedlock bed.

4. In one saying the Hanafis are of the view that desertion is by eschewal of sexual intercourse at a time in which the wife is desirous rather than the time in which he is desirous; because such is to discipline and reprimand and so he must discipline her rather than himself by eschewing intercourse in case he is in need of it (Al-Kāssānī, 1982, 2:334).

5. In one saying of the Hanbalīs (Al-Mardāwī, 8:376) the view is held that Hajr signifies not having intercourse with her in bed nor to speak to her. This position was also held by Ibn Abbas in a narration. (Ibn Kathīr, 1981, 1: 493). It is the view of Ibn Abbas in a narration according to him, Al-Sadiy, Al-Dahhak and Ikrimah in the generation succeeding the earliest generation of Muslims that Hajr is neither to have intercourse with her nor to speak to her, but to sleep in bed and then to give her his back (Ibn Kathīr, 1981, 1:493).

6. In one saying of the Shāfi '̄s the position is held that Hajr is to speak to his wife harshly, but does not eschew having intercourse with her or sharing her bed.(Al-Shirbīnī, 3: 259) This was also said by Ibn Abbas, Ikrimah and Al-Hassan in another narration (Al-Tabarī, 1985, 5:65; Ibn Al-'Arabī, 1:533).

7. It is the view of Imam Al-Tabari that Hajr is by confining the wife to the house (Al-Tabarī, 1985, 5:66). He grounded the abovementioned opinions in the Qur'ānic Āyah: “As to those women on whose part you see ill conduct, admonish them (first), (next), refuse to share their beds, (and last) beat them (lightly, if it is useful)" [An-Nisa: 34] where the Āyah was interpreted that if the wives refuse to desist from their 
rebelliousness then they should be confined to their homes (Al-Tabarī, 1985, 5:66).

Moreover, there is the narration according to Asma' the daughter of Abu Bakr the wife of Al-Zubayr Bin Al-Awam: "that she used to be outside of the home and she was reprimanded for this and he beat both of them hard, but the other wife protected herself more... and Asma' was hit more.. and she told about him to her father Abu Bakr, and he told her: be patient for AlZubayr is a good man and perhaps your spouse in paradise..." (Ibn Al-Arabi, 1:533). This tradition was narrated by Ibn Sa`ad, 1990, 8:197, and Ibn Assākir, 1998, 69:16. Al-Albānī said: the transmitters of the tradition are reliable but the chain of transmission is incomplete; because Ikrimah did not encounter $\mathrm{Abu}$ Bakr, but he received it from Asmā' Bint Abu Bakr (AlAlbān̄i, 1995, 3:276).

The opinion cited by Imam Al-Tabarī is reprehensible and alien, but I mentioned it here to discuss it and unveil its weakness as an argument, because there are those who attempt to present an erroneous view of the position of Islam on woman by referring to these alien opinions. Thus Ibn Al-'Arabī comments on the statement of Imam Al-Tabarī: "Strange it is that in spite of his erudition in the language of the Arabs that he shall have deviated from sound judgment." (Ibn Al-'Arabī, 1:534).

Thus Hajr means eschewal of the bed rather being confined to the home (Ibn Al-'Arabī, 1:534).

As to the narration according to Asma' it is an weak hadīth related by Ibn Wahb from Imam Mālik (Ibn Al-'Arabī, 1:534).

As to the other opinions interpreting the meaning of Hajr what is plausible is that desertion of the wedlock bed relates to multiple meanings, even though the apparent meaning relates to not sleeping with the wife in the same bed which is a manner of disciplining the wife.

Nonetheless, this does not prevent the use of other means in terms of eschewing oral communication or sexual intercourse without abandoning the wedlock bed which would achieve the aim of Hajr, namely to discipline the wife and prevent her disobedience, while emphasizing in this context that choosing the method of Hajr must give due regard to not causing harm to the offspring.

The position favoring variety in the meanings of desertion has been given weight by a number of modern scholars among those who have written on the section of the desertion of the wife (Zaydān, 2000, 7:315;
Shind̄̄, 2015, 134-135; Al-Rifā'̄ and Tawālbeh, 2009, 449).

\section{Duration of Hajr (Desertion):}

The lawful duration of desertion varies according to the method of Hajr to be chosen by the husband, whereby if desertion is by eschewing sexual intercourse the fuqaha hold several opinions in this matter:

1. Hanafīs (Al-Kāssān̄̄, 1982, 2:334; Ibn Nujaym, 3:236), Shāfi'īs (Al-Shirbīnī, 3:259; AlDimyātī, 3:376; Al-Mahallī, 1995, 3:307) and Hanbalīs (Al-Bahoūt̄̄, 1982, 5:209; Al-Ruheibānī, 5: 287; AlMardāwī,8;376) that it is permissible for the husband to desert his wife until she becomes obedient to him, and when she becomes so it is prohibited for him to desert her, and they did not specify for this a time period. They based their position on the āyah: "refuse to share their beds" [An-Nisa: 34] where the latter does not indicate restriction.

2. It is the position of the Mālikīs that the duration of laudable Hajr is one month and should not amount to four months (Al-Hāttāb, 1978, 4:15; Alīsh, 1989, 3:545; Al-Dussūqī, 2:343). As to their evidence for favoring Hajr for one month there is what is stated in the hadith of Umm Salamah: ((The Prophet (S.A.W) took an oath that he would not enter upon some of his wives for one month. But when twenty-nine days had elapsed, he went to them in the morning or evening. It was said to him, "O Allah's Prophet! You had taken an oath that you would not enter upon them for one month." He replied, "The month can be of twenty-nine days.))

Regarding their condition for the Hajr not to reach four months they grounded this in the period of Ilaa (oath not to have sexual relation) because the husband if he deserts his wife four months and more it is incumbent upon him to return to his wife, and in case he exceeds the period the wife has the option to separate (Al-Qurtubī, 3:108; Al-Hāttāb, 1978, 4:15) based upon the Qur'ānic āyah: 'Those who take an oath not to have sexual relation with their wives must wait four months, then if they return (change their idea in this divorce, then Allah is All-Hearer, All-Knower." [Al-Baqarah: 226-227].

3. It is the position of the Hanbalīs in one narration that he shall not desert the wedlock bed except for three days (Al-Mardāwī, 8:376).

What is the most plausible in this matter is the position of the Mālikīs in terms of determining the period of desertion, because the aim is to discipline, 
whereby if the period is prolonged to no avail, then it should be eschewed and a new means should be utilized. Moreover, eschewing sexual intercourse with the wife for four months or more does harm to the wife and the rule regarding it is that of Ilā'.

Moreover, not defining the period of Hajr may drive the morally weak to desert their wives and to do harm to them on grounds of disciplining them and this might last for years, whereby the desired aim is not fulfilled, but rather leads to aloofness between husband and wife thereby negatively affecting the Muslim family and the children in particular, and the outcome might be the dissolution of the family through divorce after prolonged suffering.

It is necessary to state here that among the exponents of the first statement are those that conferred on the wife the right to demand separation in case the desertion (Hajr) is prolonged, where they did not specify the period of lawful desertion, but when they considered the harm that could be caused by desertion they gave the wife the right to demand separation.

However, if Hajr is by eschewal of oral communication, and the matter related to him and obedience to him, the Hanafĩs (Ibn Abidīn, 7:143), Mālikīs (Al-Nafrāwī, 2:294; Al-Mawāq, 1978, 4:478; Al-Adaw̄̄, 1994, 2:428), Shafii 'is (Al-Shirāzī, 2:487; Al-Ramlī, 1984, 6: 390; Al-Mahallī, 1995, 3:307), and Hanbalīs (Al-Mardāwī, 8:276; Al-Baḥoūtī, 5:209; AlRuheibānī, 5:287), held the position that Hajr (desertion) should not exceed three days. This is attributable to the hadith of Anas Ibn Malik that the Prophet (S.A.W) said: ((...and it is impermissible for a Muslim to desert his brother for more than three nights.))

Nevertheless in case the desertion by eschewing oral communication aims to deter her from committing a sin and to rectify her religious commitment it is the position of the Hanafīs (Ibn Abidīn, 2001, 7:143), Mālikīs (Al-Nafrāwī, 2:294; Al-Adawī, 1994, 2:428), and Shāfi ‘̄is (Al-Shirbīn̄̄, 3:259; Al-Ramlī, 1984, 6: 390; Al-Mahallī, 1995, 3:307) that there is no objection for the period to be more than three days.

They based their opinion on the hadith of $\mathrm{Ka}^{\mathrm{a}} \mathrm{ab}$ Ibn Mālik in the story of his failure to participate in the Battle of Tabuk: ((Allah's Messenger (S.A.W) forbade the Muslims to talk with three of us from amongst those (persons) who had stayed behind him. The people began to avoid us and their attitude towards us underwent a change and it seemed as if the whole atmosphere had turned (hostile) against us and it was in fact the same atmosphere of which I was fully aware and in which I had lived (for a fairly long time). We spent fifty nights...)) (Al-Bukhārī, 1987 4: 1603-1605).

The preferable and sounder position in this matter is that there is no objection for the desertion by refraining from oral communication to exceed three days in order to prevent the wife from committing a sin or transgressing the commands of Allah, but it is necessary to determine when the desertion ends; because it is a means for disciplining and it is not an aim in itself, while its continuance for a long time negatively affects the Muslim family.

I wish to mention in this context that deserting the corrupt people while affirming its lawfulnessdiffers in nature from deserting the wife who resides with her husband in a single home with the children; and here we might ask how would such affect them as they observe their parents not talking to one another. Hence, choosing the suitable method of desertion is desirable in such cases, while emphasizing that it is necessary to adopt the method of preaching so as to achieve the desired end and it is God who knows best.

\section{Harming the Wife by Desertion and its Impact}

This includes three subsections:

\section{The Right of the Wife to Sexual Intercourse and Matrimonial Cohabitation:}

It was noted that desertion of the wife is considered a lawful means to discipline her and to prevent her disobedience, and that the Hajr is subject to rules and restrictions, but if such desertion continues and lasts for long then it would be harmful to the wife, especially since there are some husbands who intend to harm their wives where the matter has to do with differences unrelated to disciplining or the intention to rectify conduct, which involves affecting the right of the wife to sexual intercourse and familial tranquility and stability.

Some scholars have resultantly taken the position that the wife may demand separation between her and her husband in case the latter persists in his desertion and commission of harm.

To discuss this matter it is necessary to exposit the position of the religious scholars concerning the right to sexual intercourse- whether it is the right of the husband or the rights of both the husband and wife. 
The Ḥanafīs (Al-Kāssānī, 1982, 2: 331; Ibn AlHumām, 3:435; Ibn Nujaym, 3:235), Mālikīs (AlHattāb, 1978, 4:11), and Shāfi'īs (Al-Shirbīn̄i, 3:251; Al-Ansārī, 3:229) have stated in one opinion that sexual intercourse is the right of the husband; while the Hanafīs (Ibn Nujaym, 3:235; Ibn Abidin, 2001, 3:203), Mālikīs (Al-Muwāq, 1978, 4:108) and Hanbalīs (Ibn Qudāmah, 8:138; Al-Mardāwī, 8:354; Al-Bahoūtī, 1982, 5:192), held in one opinion that the right to sexual intercourse is the right of both man and wife. They based their aforementioned opinion on the hadith of Abdullah Bin 'Amru Bin Al-'Aas: "O 'Abdullah! Have I not been informed that you fast all the day and stand in prayer all night?" I said, "Yes, O Allah's Messenger (S.A.W)!" He said: ((Do not do that! Observe the fast sometimes and also leave them (the fast) at other times; stand up for the prayer at night and also sleep at night. Your body has a right over you, your eyes have a right over you and your wife has a right over you" (AlBukhāri, 1987, 5:1995).

The previous hadith clearly attests to the fact that the wife has rights including the right to sexual intercourse, because the Prophet (S.A.W) commanded him to fast and eat, to pray and sleep; because excessive fasting and prayer by night affects the fulfillment by the man of his matrimonial duties.

Moreover, marriage was made lawful in the interest of the married couple and to remove harm from them, by enabling licit fulfillment of sexual desire which is the right of both man and wife (Ibn Muflih, 1980, 7:198).

Therefore, the position that sexual intercourse is the right of both husband and wife is the preferred position; because such is consistent with the purposes of the marriage contract in terms of achieving empathy and tranquility, while considering the right to be solely that of the husband could lead to an inattentiveness to his wife thereby negatively affecting matrimonial life.

\section{Separation of the Spouses Due to Hajr:}

Based on what was mentioned regarding differences on the right of the married couple to sexual intercourse, the fuqaha have differed on the possibility for the wife to demand separation due to her husband deserting her and her sustaining harm as a result; there are two opinions in this regard:

1. The Hanafîs (Al-Kāssānī, 1982, 2:331; Ibn 'Abidīn, 2001, 3:202; Ibn Nujaym, 3:235), Shāfi'îs (Al-Shirāzī, 2:66; Al-Ansārī, 3:229), and the Mālikīs in one opinion (Ibn Abd Al-Barr, 1987, 1:282; Al-Kharshī, 4:93) and
Ahmad in one narration (Ibn Qudāmah,1985, 7:440; Al-Mardāwī, 9: 170) are of the view that the wife is not entitled to demand separation due to the husband deserting her and refraining from having sexual intercourse with her.

The Hanafis elaborate by saying that sexual intercourse is religiously mandatory and is thus something beyond the judicial arena and enforcement, while sexual intercourse for one time is something that is within the purview of court rulings. Those holding this opinion adduced several evidences including:

- The thing that leads to sexual intercourse and pleasure is desire and love (Al-Shirāzī, 2:66; AlRamlī, 1: 258).

- Sexual intercourse is the right of the husband and in case he eschews it he is like one who rents a house and does not use the rented house (AlAnsārī, 3:229).

- The one practicing is Ilaa is not subject to a period given that if separation is decided without an oath to eschew sexual intercourse then the Ilaa is of no consequence (Ibn Qudāmah, 1985, 7: 440).

2. In one statement the Hanafìs (Al-Kāssān̄̄, 1982, 2:331; Ibn Nujaym, 3:235; Ibn Abidīn, 2001, 3:203) Mālikīs (Malik, 4:271; Dussūq̄i 2:431; Al-Kharshī, 4:93) and Hanbalīs (Ibn Qudāmah, 1985, 7:440; AlMardāwī, 9:169-170) are of the view that the wife has the right to demand separation due to harm sustained as a result of the husband not having intercourse with her, whether the husband is present or absent. They based their opinion on several proofs including:

- Either you retain her on reasonable terms or release her with kindness. [Al-Baqara: 229]

- But do not take them back to hurt them. [AlBaqarah: 231] The mode of extrapolation from the two āyahs is that retaining the wife necessitates not doing harm to her,and refraining from sexual intercourse entails doing harm which must be removed.

- There is a narration from 'Umar Ibn Al-Khattab that he asked his daughter Hafsah - God be pleased with her - what is the longest that a woman can await her husband?, whereupon she said: six months, whereupon 'Umar did not dispatch his emissaries for more than six months ('Abd Al-Razzāq, 7: 152; Al-Bayhaqī, 9:29). In another narration he told his daughter Hafsah: "I am inquiring about a matter which has concerned me so reveal it to me; how long can a 
woman await her husband, and she looked down and was bashful, whereupon he said: Allah is not bashful of what is true, and she indicated three months or four, and then 'Umar wrote that the armies should not be kept abroad on duty for more than four months" ('Abd Al-Razzāq, 7:151-152).

- The absence of the husband from his wife causing harm which should be removed (Dussūqī 2: 431).

- In case a man eschews sexual intercourse with his wife for four months or more then this gives her the right to demand separation, and this materializes by refraining from sexual intercourse by desertion and absence; because harm is caused in both cases (Ibn Qudāmah, 1985, 7:440; Ibn Rushd, 2:76). Thus, refraining from having intercourse entails the meaning of Ilā', which is to cause harm and to eschew sexual intercourse (Ibn Al-'Arab̄̄, 1:244). Moreover, whereas the rule of Ilaa is established for one who swears this does not prevent analogical reasoning like other rules reached by analogy or qiyas (Al-Bahūtī, 1982, 5:354).

- What must be done in case one swears to eschew it must be done in case he did not swear such as expenditure on wife and other duties (Ibn Qudāmah, 1985, 7: 440).

What is plausible in this matter is the position that the wife is entitled to demand separation in case her husband deserts her and does not have intercourse with her, because such is removal of harm to her; and because one cannot imagine the continuance of a stable matrimonial relationship in a situation of Hajr.

This opinion is grounded in analogy relative to the rule of Ilā', where if a person swears not to have intercourse with his wife for four months and more, then the wife may resort to the judge to remove harm from her, for eschewal of intercourse is actualized in the case of Hajr as well as Ilā'.

As to Hajr by eschewing oral communication and bad cohabitation this involves harm to the wife and could lead to a state of divergence and dispute between the husband and wife, and this also confers on the wife the right to remove harm and to demand separation.

In this context it is necessary to point out that separation between the married coupled due to Hajr must be preceded by admonishing the husband and giving him ample opportunity to rectify his situation with his wife.
It is necessary to state here that the Mālikīs and Hanbalīs have set certain conditions as grounds for demanding separation. Thus, the Mālikīs set as a condition harm justifying demand for separation where the wife had become fearful of committing adultery, rather than sexual desire resulting from the long absence of her husband (Al-Dardīr, 2:431; Aleesh, 1989, 4:205).

As to the Hanbalīs they set as a condition for the Hajr to be without an acceptable excuse, whereby if it is due to an excuse such as sickness, absence and so forth then the demand for separation would not be valid (Ibn Qudāmah, 1985, 7:440; Al-Bahoūtī, 1982, 5:354).

As to Ibn 'Aqīl the Hanbalī he does not consider valid the claim of intending to cause harm by eschewing intercourse, where he finds possibility for demanding separation only as a result of the presence of harm (Al-Mardāwī, 9: 170).

In my opinion there is no need to set these two conditions because harm resulting from Hajr is actualized, even if the woman did not reach the extent of fear of committing adultery.

As to the presence or absence of an acceptable excuse, it may be considered on the basis of prolonging the period of grace for one with an excuse, rather than prohibiting the demand for separation; because we must view with balance both the husband and wife, whereby if the wife sustains harm by remaining with her husband in such situation, and cannot endure staying with him, then she has the right to demand separation.

\section{Duration of the Hajr Justifying Demand for Separation and the Type of Separation:}

The fuqaha differentiated between the state of Hajr and the state of absence along with Hajr or desertion.

As for the state of Hajr the fuqaha have differed on the period conferring on the woman the right to demand separation, where the Mālikīs took the position in one of their sayings (Al-Muwāq, 1978, 4:108, AlDussūqī, 2:431) and also the Hanbalīs (Al-Mardāwī, 9:169; Al-Bahoūtī, 1982, 5:354) that the period is four months by analogy to the period of Ilā'.

And in one statement by the Mālikīs they said that the separation is without a term. And in another saying, determining the period is within the discretionary power of the qāḍ̄ or judge (Ibn Abd AlBarr, 1987, 1:282; Al-Dussūqī, 2:431).

As to the state of absence with desertion the Mālikīs have adopted the position that the period is one 
year, and in another position that it is two years, or three years (Al-Dussūqīi, 2:431; Alish, 1989, 4:205).

According to the Hanbalīs the period is six months (Al-Mardāwī, 8:356) based on the narration concerning when Umar Bin Al-Khattab asked Hafsah about how long the wife can endure being away from her husband, and accordingly he would bring back his armies after six months.

The position that I find more plausible is that the period is four months by analogy to the period of Ilā; as for the state of absence it is one year, given that there could be an excuse for the absence of that husband.

As to Hajr, if it is by means of silence the Mālikīs (Al-Kharshī, 4:93; Al-Dussūqī, 2:431, Alish, $1989,4: 205$ ) hold the position that it would be possible to demand separation due to it without defining a time period after admonishing him.

As regards the type of separation due to Hajr and absence the religious scholars have differed:

According to the official position of the Mālikīs (Al-Muwāq, 1978, 4:25; Al-Dussūqī, 2:364) and the Hanbalīs (Ibn Muflih, 1980, 8:28) in one narration it is irrevocable divorce; because it is separation to remove harm at the behest of a ruler. And there is a statement by the Mālikīs (Al-Nafrāwī, 1995, 2:47; Al-Dussūqī, 2:364) and the Hanbalīs (Al-Mardāwi, 9:191; AlBahūtī, 1982, 5:368) in one narration it is revocable divorce; because the judge takes the place of the husband in effecting divorce. As to the official position of the Hanbalīs they said that separation is not diminished by the times of divorce; because every separation at the behest of the judge is dissolution (AlMardāwī, 9:191; Ibn Qudāmah, 1985, 7:147; AlRuhaibān̄̄, 5: 506).

The Hanbalīs in one narration stated that the ruler or judge has the choice of effecting divorce or dissolution (Ibn Muflih, 1980, 8:28; Al- Bahūtī, 1982, $5: 368)$.

The position that I find most plausible - and Allah knows best - separation is irrevocable divorce; because the judge admonishes the husband to mend his ways with his wife and leaves it up to the husband to divorce and if he fails to mend his ways and refuses to divorce, then the qadi shall order irrevocable divorce instead of the husband. We do not state here that the divorce is revocable; because the husband could return her and might repeat doing harm to her, and we do not say severance; because the husband after being admonished is not considered free of blame in case he insists on harming the wife, for effectuating the divorce means counting the number of divorces, and so if he return with a new contract to his wife then it shall be reckoned among the number of divorces, and this could prevent him from repeating the harm he commits.

\section{Conclusions}

Upon completion of this study with the grace of Allah, it would be possible to state several findings, foremost of which:

1- The desertion of the wife is considered among the lawful methods of disciplining which may take place after advising and preaching to the wife, such in case the wife disobeys her husband.

2- The scholars have several interpretations regarding the method of desertion, most prominently, abandoning the bed or eschewing sexual intercourse or oral communication with the wife or speaking harshly to her. The author favors the position that Hajr is suitable for being ascribed to its various meanings, whereby the husband may choose the method which is of impact and which helps in ending the disobedience of the wife in a manner not affecting the interests of the children.

3- The desertion of the wife should be period-specific and it is impermissible for it to last for numerous months or years; because Hajr has the aim of reforming the wife and ending her disobedience and in case such as abortive, then another method should be used to achieve the required aim.

4- In case the period of desertion exceeds the period that is religiously lawful, or desertion is adopted as a means to harm the wife, this confers on her the right to resort to the judiciary, so as to admonish the husband or to give him a period of time to mend his ways with his wife, and in case he continues the desertion, then the author favors for there to be separation.

5- The period of desertion enabling the wife to demand separation according to the author is four months in case the husband is living with the wife based on an analogy to Ilaa, and one year if he is absent, but if the desertion is by eschewing oral communication and mistreating the wife then the husband is not given a grace period, but shall be warned, and if he persists then there shall be immediate separation.

6- The type of separation resulting from the decision of the judge is revocable divorce, which is the position favored by the author. 


\section{References}

Abd Al-Razzāq, Abu Bakr. 1983. Mussanaf Abd Al-

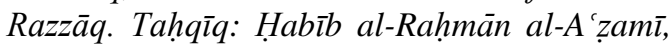
Beirūt: al-Maktab al-Islamī.

Al-Dumayri,Muhammad. 2004. al- Najm Al-Wahāj Fì Sharh al-Minhāj. Jeddah: Dār al-Minhāj.

Al-Albānī, Muhammad. 1985. Irwā' al-Ghalīl. Beirūt: al-Maktab al-Islāmī.

Al-Albānī, Muhammad. 1995. Silsilat al-Ahāàith alSah̄ihah. Riyad: Maktabat al-Ma'arif.

Al-Ansārī, Zakariyā. Asnā al-Matālib Fī Sharh Rawạ al-Țālib. al-Maktabah al-Islamiyyah.

Al-Asfahan̄̄, al-Hussayn. al-Mufradāt F̄̄ Gharīb alQur'ān. Taḥqīq: Muḥammad Kīlanī. Beirūt: Dār al-Ma'rifah.

Al-Bahūtī, Manșūr. 1982. Kashāf al-Qinā̌r. Taḥqūq: Hilāl Musaylaḥ̄ Hilāl, Beirūt: Dār al-Fikr.

Al-Bayhaqī, Aḥmad. 1994. Sunan al-Bayhaqī. Tahquīq: Muhammad Atā. Mecca: Maktabat Dar al-Bāz.

Al-Bukharī, Muhammad. 1987. Saḥ̄h al-Bukharī, Tahquīq: Mustafā al-Bughā, Beirut: Dār Ibn Kathīr.

Al-Dardīr, Ahmad. al-Sharh al-Kabīr, Tahquiqq: Muhammad 'Alīsh, Beirūt: Dār al-Fikr.

Al-Dimyātī, Abu Bakr. I'ānat al-Tālibīn. Beirūt: Dār al-Fikr.

Al-Dussūqū, Muhammad. Hāshiyat al-Dussūqī 'Ala alSharh al-Kabìr. Taḥqìq: Muhammad 'Alìsh. Beirūt: Dār al-Fikr.

Al-Fayrūz Abādì, Muḥammad. al-Qāmūs al-Muḥịt. Beirūt: Mu'assasah Al-Risālah.

Al-Hākim, Muhammad. 1991. Mustadrak al-Hākim. Tahqūq: Mustafā Atā. Beirūt: Dār al-Kutub alIlmiyyah.

Al-Hattāb, Muhammad. 1978. Mawāhib al-Jal̄̄l Sharh Mukhtassar Khalīl. Beirūt: Dār al-Fikr.

Al-Jassās, Aḥmad. 1985. Aḥkām al-Qur'ān. Taḥīq: Muhammad al-Sadiq Qamhāwī. Beirūt: Dār Ihyā' al-Turāth.

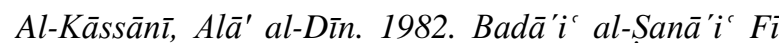
Tartīb al-Sharā'íc. Beirūt: Dār al-Kitāb al'Arabī

Al-Kharshī, Muhammad, Sharh al-Kharshī 'Ala Mukhtassar Khalīl. Beirūt: Dār al-Fikr.

Al-Mahallī, Jalāl Al-Dīn. 1995. Sharh al-Mahallì 'Ala al-Minhāj. Beirūt: Dār al-Fikr.

Al-Manāwī, Muhammad. 1990. al-Tawqīf 'Ala Muhimmāt al-Ta'ārif. Taḥqiqq: Muḥammad alDāyah. Beirūt: Dār al-Fikr al-Mu'āsir.

Al-Mardāwī, Alī. al-Insāf Fì Ma 'rifat al-Rājị̆ Min alKhilāf. Tahqiq: Muhammad al-Faqì, Beirūt: Dār Ihyā' al-Turāth.

Al-Muwāq, Muhammad. 1978. al-Tāj Wa al-Iklīl. Beirūt: Dār al-Fikr.
Al-'Adawī, 'Alī. 1994. Hāshiyat al-'Adawī 'Ala Sharh Kifāyat al-Tālib al-Rabbānī. Taḥqūq: Yūsuf AlBiqā' ì. Beirūt: Dār al-Fikr.

Al-Nafrāwī, Ahmad. 1995. al-Fawākih al-Dawānī. Beirūt: Dār al-Fikr.

Al-Nassā' '̄, Ahmad. 2001. al-Sunan al-Kubrā. Tahqūq: Hassan Shalabī, Beirūt: Mu'assasat al-Risālah.

Al-Nawāwī, Yahyāa. 1985. Rawdat al-Tālibìn. Beirūt: al-Maktab al-Islāmī.

Al-Qurtubī, Muhammad. 1964. al-Jāmi` Li Ahkām alQurān. Taḥqīq: Aḥmad al-Bardan and Ibrāhìm Itfeash. Cairo: Dār al-Kutub al-Masriyah .

Al-Ramlī, Muhammad. 1984. Nihāyat al-Muhtājj. Beirūt: Dār al-Fikr.

Al-Ramlī, Muhammad. Ghāyat Al-Bayān Sharh Zubad Ibn Raslān. Beirūt: Dār al-Ma'rifah.

Al-Rifāi '`̃, Rudayna, and Tawālbeh, Muhammad. 2009. Ahkām al-Hajr F̄̄ al-Fiqh al-Islamī. Majallat Dirāssāt Ulum al-Shari'ah wa al Qānūn. University of Jordān. Vol. 36, Issue 2.

Al-Ruhaybānī, Mustafā. Matālib Uli al-Nuhā. Damascus: al-Maktab al-Islamī.

Al-Sharbin̄̄, Muhammad. Mugnī al-Muhtāj. Beirut: Dār al-Fikr.

Al-Shīrazī, Ibrāhīm. al-Muhadhab Fī Fiqh al-Imām alShāfi'ì. Beirūt: Dār al-Kutub al-'Ilmiyyah.

Al-Tabarī, Muhammad. 1985. Tafsīr al-Tabarī. Beirūt: Dār al-Fikr.

Al-Tirmidhī, Muhammad. Sunan al-Tirmidhī, Tah̆qūq: Aḥmad Shākir. Beirūt: Dār Ihyā̄' Al-Turāth.

Al-Zarqān̄ì, 'Abd al-Bāqī. 2002. Sharḥ al-Zarqān̄̄ Ala Mukhtasar Khalīl. Taḥqīq: 'Abd al-Salam Amin. Beirūt: Dār al-Kutub al-'Tlmiyyah.

Ibn al- 'Arabī, Muhammad. Ahkām al-Qur'ān, Tahquīq: Muhammad Atā, Beirūt: Dār al-Fikr.

Ibn al-Humām, Muhammad. Fath al-Qadīr. Beirūt: Dār al-Fikr.

Ibn Assāker, Ali.1998. History of Damascus. Tahquiq: 'Alī Shirī, Beirūt: Dār al-Fikr.

Ibn Kathīr, Isma '̄l. 1981. Tafsīr al-Qur'ān al-'Azìm. Beirūt; Dār al-Fikr.

Ibn Mājah, Muḥammad. Sunan Ibn Mājah. Taḥqīq: Muhammad Fu'àd 'Abd al-Bāqū, Beirūt: Dār alFikr.

Ibn Manżūr, Jamāl al-Dīn. Lisān al-Arab. Beirūt: Dār Sādir.

Ibn Muflih, Ibrahīm. 1980. al-Mubdi`. Beirūt: alMaktab al-Islamī.

Ibn 'Abd al-Barr, Yūsuf. 1987. al-Kāfî. Beirūt: Dār alKutub al-'Ilmiyyah.

Ibn Nujaym, Zayn al-Dīn. al-Bahrr al-Rā iq Sharh Kanz al-Daqā iqq. Beirūt: Dār al-Ma`rifah.

Ibn 'Ābidīn, Muhammad .2001. Hāshiyat Ibn 'Ābidīn. Beirūt: Dār al-Fikr. 
Ibn Qudāmah, Abdullah. 1985. al-Mughnī. Beirūt: Dār al-Fikr.

Ibn Rushd, Muḥammad. Bidāyat al-Mujtahid Wa Nihayat al-Muqtasid. Beirūt: Dār al-Fikr.

Ibn Sa'd, Muhammad. 1990. al-Tabaqāt al-Kubrā. Taḥqūq: Abd Al-Qādir Atā, Beirūt: Dār alKutub al-Ilmiyyah.

Mālik, Ibn Anas. al-Mudawwannah al-Kubrā. Beirūt: Dār Sādir.

Muslim, Ibn al-Hajjāj. Sahīh Muslim. Tahqiq: Muhammad Fu'ād 'Abd al-Bāqū. Beirūt: Dār Ihyō' al-Turāth.

'Alīsh, Muhammad. 1989. Manh al-Jalīl. Beirūt: Dar al-Fikr.

Shind̄̄, Ismā'īl. 2015. Hukm Hajr al-Zawjah fì al-Fiqh al-Islamī. Journal of al-Quds Open University for Research and Studies. al-Quds Open University. Issue 36.

Zaydān, 'Abd al-Karīm. 2000. al-Mufașsal fī Ahkām alMar'ah wa al-Bayt al-Muslim. Beirūt. Mu'assasah Al-Risālah. 